MaPan :JurnalMatematikadanPembelajaran

p-ISSN: 2354-6883 ; e-ISSN: 2581-172X

Volume 6, No 2, December 2018 (173-186)

DOI: https://doi.org/10.24252/mapan.2018v6n4

\title{
PENGEMBANGAN BUKU KEAJAIBAN ANGKA DALAM ALQUR'AN DILENGKAPI MEDIA KARTU ANGKA
}

\author{
Annisah Kurniati1), Hayatun Nufus ${ }^{2}$ \\ 1,2Universitas Islam Negeri Suska Riau \\ 1,2Jalan H. R. Subrantas Km. 15 Pekanbaru \\ E-mail: annisa.kurniati@gmail.com ${ }^{1}$, ${\left.\text { hayatun.nufus@uin-suska.ac.id }{ }^{2}\right)}^{2}$
}

Submitted: 23-04-2018, Revised: 09-06-2018, Accepted: 02-07-2018

\begin{abstract}
Abstrak:
Tujuan penelitian ini yaitu untuk menghasilkan buku keajaiban angka dalam Alqur'an yang valid dan praktis. Metode penelitian yang digunakan adalah penelitian pengembangan yang terdiri dari tiga tahapan yaitu tahap analisis mukabelakang (front-end analysis), tahap prototipe (prototype) dan tahap penilaian (assessment). Pengumpulan data dilakukan dengan cara observasi, angket, dan dokumentasi. Jenis data yang diambil dalam penelitian ini adalah data primer, yaitu data yang diperoleh langsung dari angket. Instrumen pengumpulan data berupa angket uji validitas dan angket uji praktikalitas. Data yang diperoleh kemudian dianalisis dengan teknik analisis deskriptif. Hasil penelitian menunjukan bahwa buku keajaiban angka dalam Alqur'an valid dan praktis untuk digunakan.
\end{abstract}

Kata Kunci: Keajaiban Angka dalam Alqur'an, Media Kartu Angka

\section{THE BOOK DEVELOPMENT OF THE MIRACLE OF NUMBERS IN ALQUR'AN EQUIPPED BY NUMBER CARD MEDIA}

\begin{abstract}
:
The research aims to produce a valid and practical book of miracle of numbers in the holy Qur'an. The research method used was a developmental research consisting of three stages, namely, front-end analysis, prototype, and assessment stage. Data collection was conducted through the observation, questionnaire, and documentation. The types of data taken in this research were the primary data; it was the data that were directly obtained from the questionnaire. Data collection instruments were in the forms of validity test questionnaire and practicality test questionnaire. The data obtained were then analyzed by using descriptive analysis techniques. The research findings showed that the book of the miracle of numbers in the holy Qur'an is valid and practical to use.
\end{abstract}

Keywords: Miracle of Numbers in Al-Qur'an, Number Card Media

How to Cite: Kurniati, A., \& Nufus, H. (2018). Pengembangan Buku Keajaiban Angka dalam Al-Quran Dilengkapi Media Kartu Angka : Jurnal Matematika dan Pembelajaran, $6(2), 173-186$. 
$Q^{a}$ alah satu konsep matematika sederhana yang diajarkan kepada anakanak yaitu mengenai angka. Kesadaran anak terhadap bilangan dapat dirangsang melalui belajar angka (Mutiah, 2010). Anak akan terbiasa dengan aktivitas hitung-menghitung saat bermain jika angka-angka dipelajari sebagai bagian keseharian dan rutinitas. Jika anak telah terbiasa dan menyukai belajar berhitung, hal ini akan dapat dijadikan dasar bagi anak untuk mengembangkan kemampuan matematika pada tahap yang lebih tinggi.

Penggunaan berbagai macam permainan dan benda-benda dalam kehidupan sehari-hari sangat baik dilakukan dalam mengenalkan konsep angka atau matematika dasar kepada anak. Dengan bermain anak belajar dalam kondisi menyenangkan tanpa ada paksaan, sehingga anak akan lebih mudah dalam memahami berbagai konsep mengenai angka. Bermain merupakan suatu kegiatan yang tepat bagi anak untuk bereksplorasi dan belajar (Fitria, 2013). Berdasarkan penelitian Lestariningrum (2015), anak lebih mudah memahami konsep mengenal bilangan karena dilakukan dengan bermain yang menyenangkan serta anak diajak bereksplorasi, menemukan dan memanfaatkan objek-objek yang dekat serta konkret. Hal ini diperkuat dengan hasil penelitian Maryani (2010) yang berhasil mencapai ketuntasan sebesar $84 \%$ dengan melaksanakan pembelajaran mengenai konsep angka melalui permainan.

Dalam mengenalkan angka kepada anak sebaiknya dilakukan bersamaan dengan penanaman ilmu agam Islam. Hal ini karena matematika dalam mengenalkan angka memiliki peran dalam pengembangan potensi intelek manusia yang merupakan amanat Tuhan yang harus dipertangggungjawabkan. Jika dapat mengintegrasikan ilmu keislaman dari setiap konsep matematika salah satunya mengenai angka, maka tentunya akan lebih mudah mengembangkannya dalam setiap proses pembelajaran (Kurniati, 2015). Dengan demikian dari sejak dini kita mengajarkan bahwa matematika dasar yang dimulai dari angka memiliki kaitan yang erat dengan ilmu agama atau nilai-nilai Islam.

Mengenalkan angka dan mengaitkan dengan ilmu agama atau nilainilai Islam, secara tidak langsung mengenalkan kepada anak bahwa ternyata semua hal mulai dari masalah terkecil seperti angka ada dibahas dalam Islam yang berpedoman pada Alqur'an dan Sunnah. Angka memiliki kedudukan yang penting dalam berbagai aspek kehidupan. Al-Khawarizmi adalah tokoh matematikawan muslim yang pertama kali menemukan notasi angka. Buku yang ditulis al-Khwarizmi berjudul Al-Jabr wa al-Muqabalahfi Ilm al-Hisab 
merupakan buku yang menjadi dasar bagi pengetahuan matematika khususnya pengaplikasian angka (Mohamed, 2004). Angka sebagai dasar matematika merupakan hasil pemikiran dan penalaran manusia yang bertumpu pada logika dan daya cipta. Angka merupakan salah satu konsep matematika yang paling penting dipelajari oleh anak (Seefeldt \& Wasik, 2008). Hayuningtiyas (2014) menyatakan bahwa konsep matematika yang diajarkan kepada anak meliputi pengenalan angka, pengenalan aljabar (menggolongkan, membandingkan, menyusun, pengenalan pola, pengenalan geometri, dan pengukuran). Oleh sebab itu, mengajarkan angka kepada anak sangat penting.

Berikut merupakan beberapa contoh ataupun cerita yang sangat bagus bila dikenalkan kepada anak-anak mengenai beberapa contoh angka dalam Alqur'an. Angka 1 menunjukan Allah itu satu atau Esa ada di dalam QS.AlIkhlas. Kemudian cerita nabi Musa di dalam Alqur'an yang mengaitkan angka-angka beserta operasinya yaitu pada QS. Al-A'raaf ayat 142 “Dan kami telah menjanjikan kepada Musa (memberikan Taurat) tiga puluh malam, dan Kami sempurnakan jumlah malam itu dengan sepuluh (malam lagi), maka sempurnalah waktu yang telah ditentukan Tuhannya empat puluh malam". Angka yang disebutkanya itu angka 30 dan 10, sedangkan operasi matematika yang dilakukan adalah penjumlahan yang menghasilkan angka 40 sehingga 30 $+10=40$.

Keajaiban angka dalam Al-qur'an Surat Al-Ankabut ayat 14 juga terdapat dalam cerita Nabi Nuh yaitu "Dan sungguh, Kami telah mengutus Nuh kepada kaumnya, maka dia tinggal bersama mereka selama seribu tahun kurang lima puluh tahun. Kemudian mereka dilanda banjir besar, sedangkan mereka adalah orang-orang yang zalim". Operasi yang dilakukanya itu pengurangan 1000 tahun - 50 tahun.

Keajaiban angka pada Alqur'an pada operasi perkalian dan pembagian salah satunya terdapat dalam QS Al-Baqarah 261. "Perumpamaan orang-orang yang menafkahkan hartanya di jalan Allah adalah sama dengan sebutir benih yang menumbuhkan tujuh tangkai, pada setiap tangkai tumbuh 100 biji. Allah melipat gandakan (balasan) bagi siapa yang Dia kehendaki, dan Allah Maha Luas (karunia Nya) lagi Maha Mengetahui." Ayat tersebut menjelaskan bahwa akan terasa berat menafkahkan sebagian harta di jalan Allah dibandingkan dengan menafkahkan sebagian harta untuk kemaksiatan. Oleh karena itu pada QS Al-Baqarah 261 Allah menyediakan ganjaran pahala yang berlipat ganda sebesar 700 kali lipat bahkan hinggaj umlah yang tak terhingga. Jika kandungan ayat ini dicermati, maka dapat diketahui bahwa nilai balasan yang 
akan diterima si pemberi berbanding lurus dengan nilai keikhlasannya saat berbagi kepada orang lain. Dengan kata lain balasan berbanding terbalik dengan besar harapan memperoleh imbalan dari manusia terhadap pemberiannya itu. Kandungan ayat ini dapat dijelaskan dengan pendekatan matematika melalui pembagian.

Sangat banyak keajaiban angka-angka yang diceritakan dalam Alqur'an. Keajaiban-keajaiban dari setiap angka, cerita-cerita mengenai angka yang terdapat dalam Alqur'an dapat dirangkum dalam satu buku yaitu Buku Keajaiban Angka dalam Alqur'an. Buku Keajaiban Angka dalam Alqur'an yang dimaksud dalam penelitian ini adalah seperangkat materi yang disusun secara sistematis dalam bentuk tertulis yang disusun berdasarkan konsep angka disertai dengan cerita-cerita terkait angka dalam Alqur'an dan gambargambar bernuansa Islami.

Agar mendapatkan buku yang berkualitas baik, pada pengembangan buku keajaiban angka memperhatikan enam elemen yaitu konsistensi, format, organisasi, daya tarik, ukuran huruf, dan penggunaan spasi kosong (Arsyad, 2011). Selain itu, untuk menganalisis dan mendeskripsikan validitas serta praktikalitas pengembangan buku tiga unsur untuk mengukur kualitas dari produk, yaitu validitas, kepraktisan dan keefektifan (Akker, 1999). Keajaiban angka dalam Alqur'an dilengkapi media kartu angka yang digunakan untuk anak dalam mengenalkan angka.

Media memiliki peranan yang penting dalam pembelajaran. Media digunakan untuk mempermudah penyampaian pesan maupun informasi. Media juga dapat merangsang pikiran, perasaan, perhatian, dan minat anak sehingga terjadi proses belajar. Briggs (Sumantri, 2004) mengemukakan bahwa media adalah segala alat fisik yang dapat menyajikan pesan dan merangsang anak untuk belajar. Jadi media dapat dijadikan sebagai alat penyampaian pesan atau informasi yang efektif dan efisien dalam pembelajaran guna mencapai tujuan pembelajaran yang diharapkan.

Untuk mencapai tujuan pembelajaran yang diharapkan, ada beberapa aspek yang perlu diperhatikan dalam penggunaan media. Angkowo \& Kosasih (2007) menyatakan bahwa untuk mengoptimalkan penggunakan media pembelajaran, aspek yang perlu diperhatikan adalah: (1) media yang bagus, menarik, jelas, dan mudah dimengerti; (2) apa yang digunakan sebagai media harus cukup penting dan cocok untuk hal serupa jika dilihat pada keadaan yang sebenarnya; (3) media harus benar dalam arti harus menggambarkan situasi yang serupa jika dilihat pada keadaan yang 
sebenarnya; (4) media memiliki kesederhanaan dalam arti tidak rumit sehingga sulit dipahami siswa; (5) media harus sesuai dengan kecerdasan orang yang melihatnya; dan (6) ukuran media harus diseuaikan dengan kebutuhan. Dengan memperhatikan aspek-aspek yang telah dijelaskan, jenis media yang digunakan dalam pembelajaran sangat bervariasi dan beraneka ragam.

Jenis-jenis media yang digunakan dalam meningkatkan pengetahuan untuk anak diantaranya adalah media serutan kayu, media gambar dan media kartu angka (Nurani, 2012). Dari ketiga jenis media yang dikemukakan, kartu angka sangat efektif dalam meningkatkan perhatian dan daya ingat anak terhadap angka-angka. Hal ini diperkuat oleh pendapat Tadkirotun (2012) bahwa kartu angka merupakan fasilitas penting dalam pembelajaran di sekolah karena bermanfaat untuk meningkatkan perhatian anak. Dengan media kartu, anak diajak secara aktif memperhatikan apa yang diajarkan guru. Selain itu, Untuk menjelaskan suatu materi tertentu, misal keadaan sebuah benda seperti bentuk angka, bangunan, dan sebagainya, dengan gambar akan lebih jelas daripada diceritakan secara lisan saja.

Berdasarkan uraian tersebut, maka media kartu angka yang dimaksud sebuah set kartu (dari angka 1 sampai 10) yang berisi angka-angka dalam Bahasa Arab dan Bahasa Indonesia. Kartu-kartu tersebut disertai dengan gambar-gambar yang disukai anak-anak dan bernuansa Islami. Kartu-kartu angka terletak di dalam buku keajaiban angka dalam Alqur'an sehingga tidak mudah hilang. Di dalam buku terdapat penjelasan tentang angka yang terdiri dari sejarah, kegunaan dan keajaiban angka dalam Alqur'an. Buku tersebut juga menyediakan permainan angka yang membuat anak tidak merasa bosan dalam belajar. Selain itu, sebagai tambahan di dalam buku dilengkapi dengan operasi hitung kali bagi tambah dan kurang (Kabataku) yang terdapat dalam Alqur'an. Media Kartu angka dan buku tersebut dilengkapi dengan gambargambar Islami dan dikemas semenarik mungkin dengan gaya dan bahasa untuk anak-anak.

Media kartu angka dapat meningkatkan kemampuan kognitif anak dalam mengenal bilangan (Sumini, 2013). Dengan menggunakan kartu angka anak menjadi aktif memperhatikan guru, sehingga perhatian anak dapat ditingkatkan dalam pembelajaran (Tadkirotun, 2012). Untuk menjelaskan materi seperti angka kepada anak, akan lebih baik jika dijelaskan dengan menggunakan gambar daripada dengan bercerita. Hal ini karena semakin kecil anak maka semakin perlu menggunakan lebih banyak media ataupun 
alat peraga yang dapat disentuh, dilihat, dirasakan, dan didengarnya (Nurani, 2012).

Berdasarkan observasi yang peneliti lakukan di salah satu Madrasah Ibtidaiyyah (MI) dan sebuah Sekolah Dasar Islam Terpadu (SD IT) di Kabupaten Kampar dan wawancara dengan guru matematika, pengenalan angka melalui media kartu angka ataupun alat peraga bagi anak sering dilakukan. Hal ini karena pengembangan dan pengenalan media atau alat peraga merupakan salah satu program di sekolah-sekolah tingkat dasar. Latar belakang diadakannya program tersebut karena melihat banyaknya anak-anak yang memiliki kemampuan mengeksplorasi benda-benda yang ada di sekitarnya. Mereka juga memiliki keinginan belajar yang luar biasa.

Pengenalan angka di beberapa sekolah selain menggunakan media kartu angka juga dapat menggunakan media poster-poster angka yang banyak di jual di toko buku. Sekolah-sekolah juga secara rutin mengadakan pelatihanpelatihan mengenai angka baik berupa permainan seperti Rangking 1, pengenalan angka dalam bahasa Inggris, belajar menulis angka dengan lembar kerja angka dan bentuk-bentuk lainnya yang dilakukan oleh guru-guru. Namun, dari sekian banyaknya cara dalam mengenalkan angka, belum ada satupun sekolah khususnya sekolah Islam yang mengaitkan dengan ilmu Keislaman. Selain itu, buku paket yang digunakan dalam mengenalkan angka juga tidak mengaitkan dengan Ilmu keislaman. Dengan demikian Integrasi antara ilmu umum dengan Islam belum terlaksana dengan baik dalam aspek pengenalan angka. Padahal menurut Kurniati (2015) Integrasi ilmu keislaman dalam pembelajaran menjadi ciri khas di lembaga pendidikan Islam.

Berdasarkan latar belakang yang telah dijelaskan dan dengan kemampuan dasar yang dimiliki oleh anak, peneliti merasa bahwa keberadaan buku keajaiban angka sangat penting untuk mengenalkan angka kepada anak dan mengaitkan dengan Islam. Oleh karena itu, perlu dikembangkannya sebuah buku keajaiban angka dalam Alqur'an yang valid dan praktis untuk digunakan dengan tujuan penelitian ini adalah menghasilkan buku keajaiban angka dalam Alqur'an yang valid dan praktis digunakan.

\section{METODE PENELITIAN}

Jenis penelitian yang digunakan adalah penelitian pengembangan (research and development/R\&D). Objek penelitian adalah buku keajaiban angka dalam Alqur'an dilengkapi dengan media kartu angka. Subjek dalam uji coba yaitu anak-anak di Taman Bacaan Anak (TBA) Hijaiyyah. 
Rancangan penelitian terdiri dari tiga tahapan yaitu: (1) Analisis mukabelakang (front-end analysis). (2) Tahap prototipe (prototype) dan (3) Tahap penilaian (assessment). Secara umum, rancangan penelitian dapat dilihat dari bagan berikut:

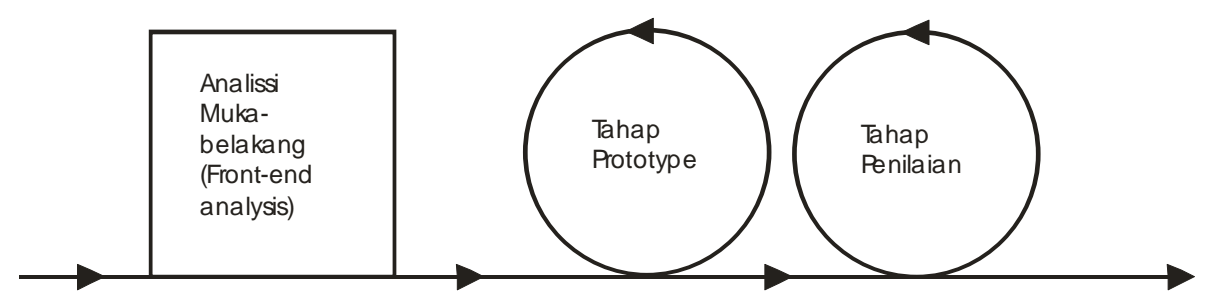

Gambar 1. Rancangan Penelitian (Fauzan, 2002)

Teknik pengumpulan data yang digunakan dalam penelitian ini adalah angket dan observasi. Lembar angket meliputi lembar angket validasi oleh ahli desain media pembelajaran, ahli materi pembelajaran matematika, dan ahli materi keislaman. Observasi digunakan bertujuan untuk mengetahui tingkat praktikalitas pelaksanaan buku keajaiban angka dalam Alqur'an dilengkapi media kartu angka dan melihat aktivitas siswa selama pembelajaran.

Teknik analisis data penelitian ini adalah analisis deskriptif kualitatif dan analisis deskriptif kuantitatif. Teknik analisis deskriptif kualitatif digunakan untuk mengolah data hasil review dari para ahli dan analisis deskriptif kuantitatif dilakukan dengan cara menganalisis data kuantitatif berupa angka yang diperoleh dari angket maupun lembar observasi.

\section{HASIL PENELITIAN DAN PEMBAHASAN}

Salah satu tujuan penelitian ini adalah untuk menghasilkan buku keajaiban angka dalam Alqur'an dilengkapi media kartu angka yang valid dan praktis. Hasil dari pengembangan tersebut dapat dideskripsikan sebagai berikut:

\section{Tahap Analisis Muka-Belakang (Front-End Analysis)}

Pada tahap ini dilakukan observasi dan wawancara untuk mengetahui potensi masalah yang terjadi di lapangan. Berdasarkan hasil observasi dan wawancara diketahui bahwa anak-anak yang belajar di TBA Hijaiyyah tidak terikat kurikulum yang ditetapkan pemerintah. TBA Hijaiyyah mempunyai program Calistung (Membaca, Menulis dan Berhitung). Buku-buku yang digunakan guru dalam mengajarkan calistung adalah buku yang disusun sendiri oleh pemilik TBA Hijaiyyah. 
Hanya saja buku-buku yang tersedia di TBA Hijaiyyah belum terintegrasi dengan ilmu keislaman, khususnya buku mengenai pengenalan angka.

Berdasarkan pemahaman anak terhadap angka, pada dasarnya sangat tinggi, hanya saja anak belum dapat menuliskan angka dengan baik dan benar. Anak juga belum mengetahui bagaimana bentuk angka arab. Dari masalah tersebut, peneliti mengumpulkan buku-buku mengenai pengenalan angka dan buku-buku yang bercerita mengenai keajaiban angka dalam Alqur'an. Buku-buku tersebut dijadikan bahan dalam mengembangkan buku keajaiban angka dalam Alqur'an.

\section{Tahap Prototipe (Prototype)}

Pengembangan buku keajaiban angka dalam Alqur'an berisi 60 halaman. Buku ini memuat materi mengenai pengenalan angka latin dan angka arab dari angka satu sampai sepuluh. Buku ini berisi mengenai keajaiban angka satu sampai angka sepuluh yang terdapat dalam Alqur'an. Di dalam buku ini anak-anak juga dibimbing untuk menulis angka, mengurutkan angka, melakukan operasi penjumlahan dan pengurangan serta permainan lainnya mengenai pengenalan angka yang dikaitkan dengan keajaiban angka dalam Alqur'an. Berikut merupakan gambar beberapa bagian isi dari buku keajaiban angka dalam Alqur'an.

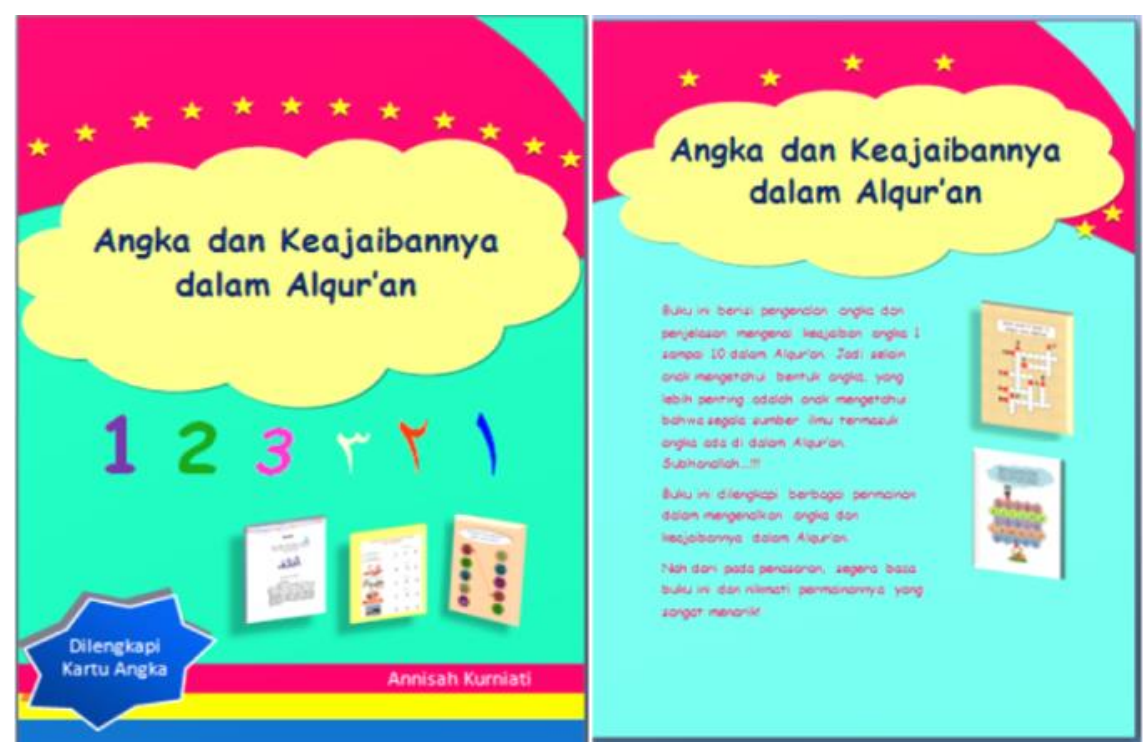

Gambar 1. Cover Depan dan Cover Belakang 


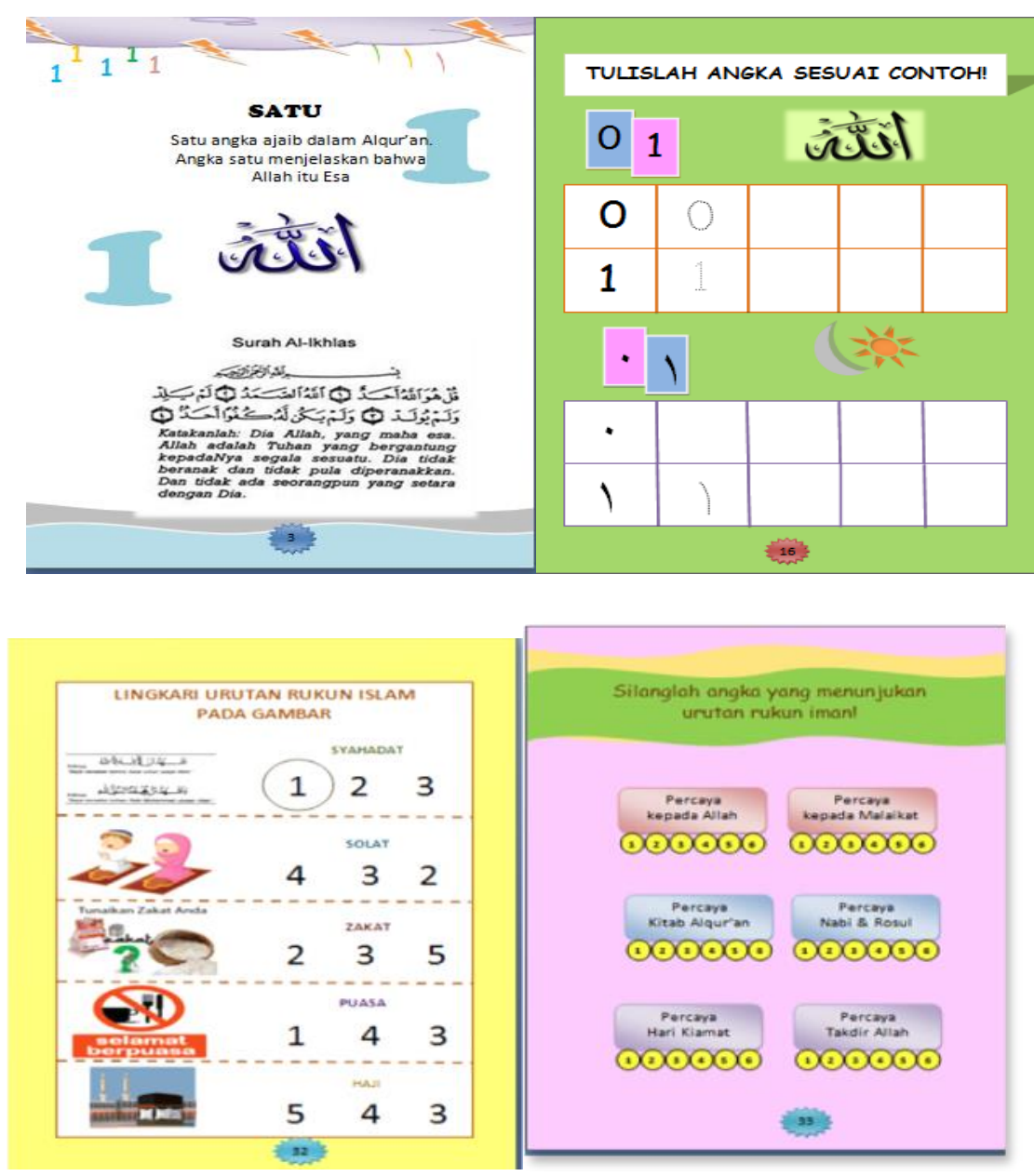

Gambar 2. Beberapa Bagian Isi dari Buku

Pembuatan prototipe ini dilakukan melalui 2 tahap yaitu tahap validasi dan tahap praktikalitas. Hasil dari tahapan tersebut sebagai berikut:

\section{a. Tahap Validasi}

Untuk mengetahui apakah produk yang dikembangkan layak atau tidak, dapat dilakukan dengan cara menghadirkan ahli desain media pembelajaran, ahli materi pembelajaran dan integrasi dengan ilmu keislaman. Review ini dilakukan untuk mengetahui hal-hal apa saja yang masih kurang dan perlu ditambahkan pada buku sebelum diujikan lebih lanjut kepada siswa. Di bawah ini disajikan hasil penilaian dan tanggapan dari para ahli desain media pembelajaran dan ahli materi pembelajaran dan integrasi dengan keislaman. 


\section{1) Validasi oleh Ahli Desain Media pembelajaran}

Menurut ahli desain media pembelajaran, buku keajaiban angka dalam Alqur'an ini layak digunakan untuk anak karena produk ini merupakan suatu ide yang bagus dan sangat kreatif, namun produk ini masih perlu direvisi kembali. Sebagai contoh seperti tampilan cover sebaiknya dikaitkan dengan ilmu keislaman. Selanjutnya Kesesuaian gambar yang digunakan dengan materi, warna yang digunakan lebih bervariasi dan ukuran huruf diperbesar sehingga cocok digunakan untuk anak.

Angket yang diberikan kepada ahli media berisi sebanyak 18 butir pertanyaan, dengan bobot skor tertinggi 5. Dari hasil analisis diperoleh jumlah total skor ahli desain media adalah 74, maka didapatkan persentase kelayakan media pembelajaran sebesar $82 \%$ artinya buku keajaiban angka dalam Alqur'an termasuk dalam kategori layak sekali untuk digunakan dalam mengenalkan angka kepada anak.

\section{2) Validasi oleh Ahli Materi Pembelajaran}

Menurut ahli materi pembelajaran produk ini layak digunakan untuk anak karena bisa menjadi alternative anak untuk belajar mengenal angka secara mandiri di rumah. Angket yang diberikan kepada ahli media berisi sebanyak 27 butir pertanyaan, dengan bobot skor tertinggi 5. Dari hasil analisis diperoleh jumlah total skor ahli materi adalah 110, maka didapatkan persentase kelayakan media pembelajaran sebesar $81 \%$ artinya buku keajaiban angka dalam Alqur'an termasuk dalam kategori layak sekali untuk digunakan dalam memfasilitasi anak untuk mengenal angka.

\section{Revisi Desain}

Semua data dari hasil validasi, penilaian, dan diskusi dengan ahli desain media dan ahli materi pembelajaran dijadikan bahan pertimbangan dalam rangka revisi penyempurnaan buku sebelum dilakukan prosedur penelitian selanjutnya yaitu uji coba lapangan terbatas. Berdasarkan komentar dan saran dari para ahli terdapat beberapa komponen buku keajaiaban angka yang perlu direvisi. Hal ini dilakukan agar produk pengembangan buku keajaiban angka yang dihasilkan menjadi lebih baik. 


\section{Penyempurnaan Produk}

Setelah melalui berbagai tahapan pengembangan produk, pada dasarnya buku yang dikembangkan oleh peneliti yaitu buku keajaiban angka dalam Alqur'an telah mengalami beberapa revisi dan perbaikan-perbaikan yang wajar. Komentar dan saran dalam buku diwujudkan dengan sebaikbaiknya sehingga produk pengembangan yang dihasilkan semakin baik. Berikut ini disajikan beberapa contoh komponen produk sebelum dan sesudah direvisi.
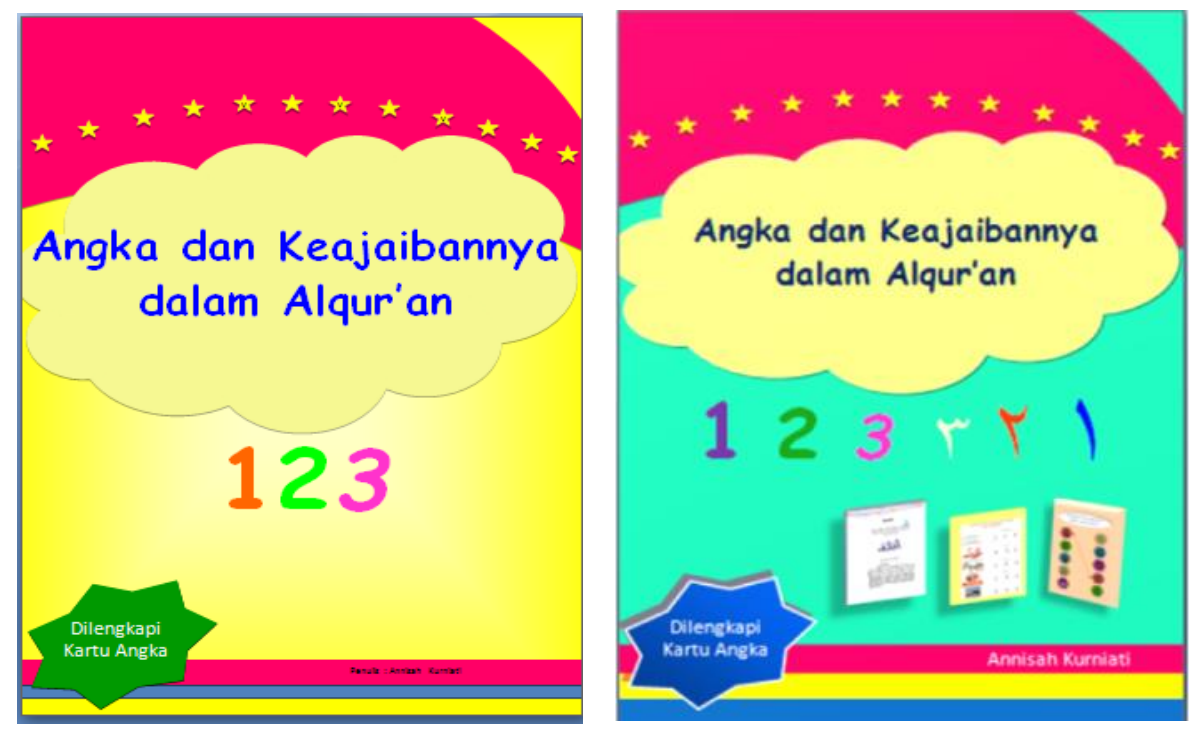

Gambar 3. Cover Buku sebelum dan sesudah Revisi
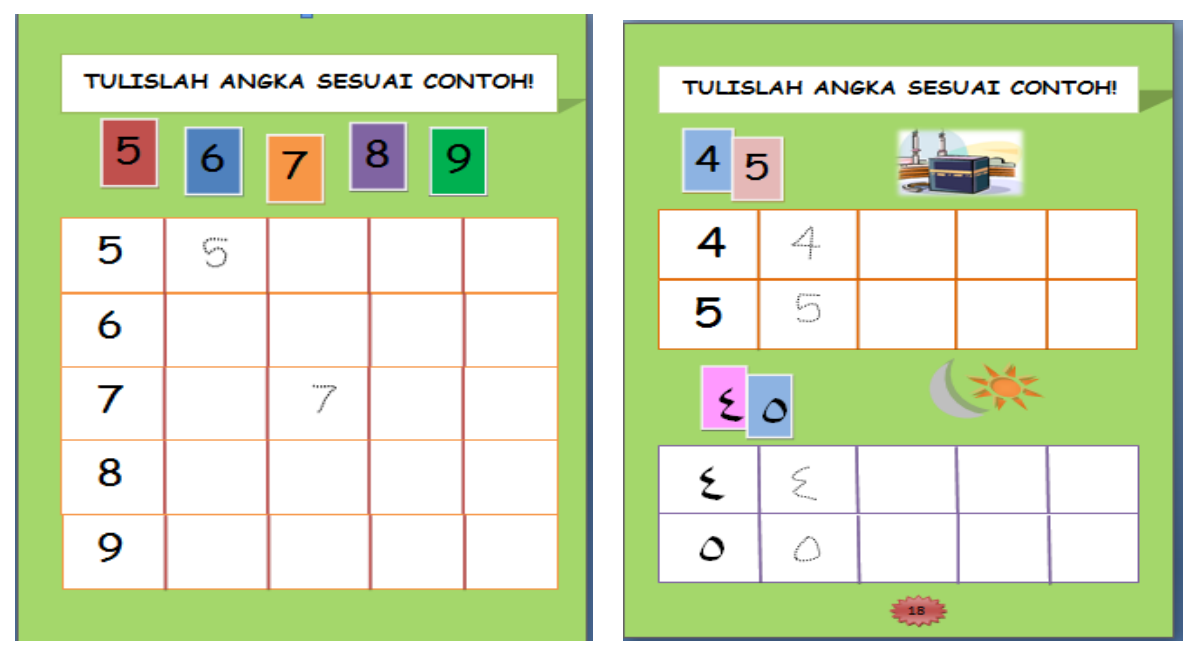

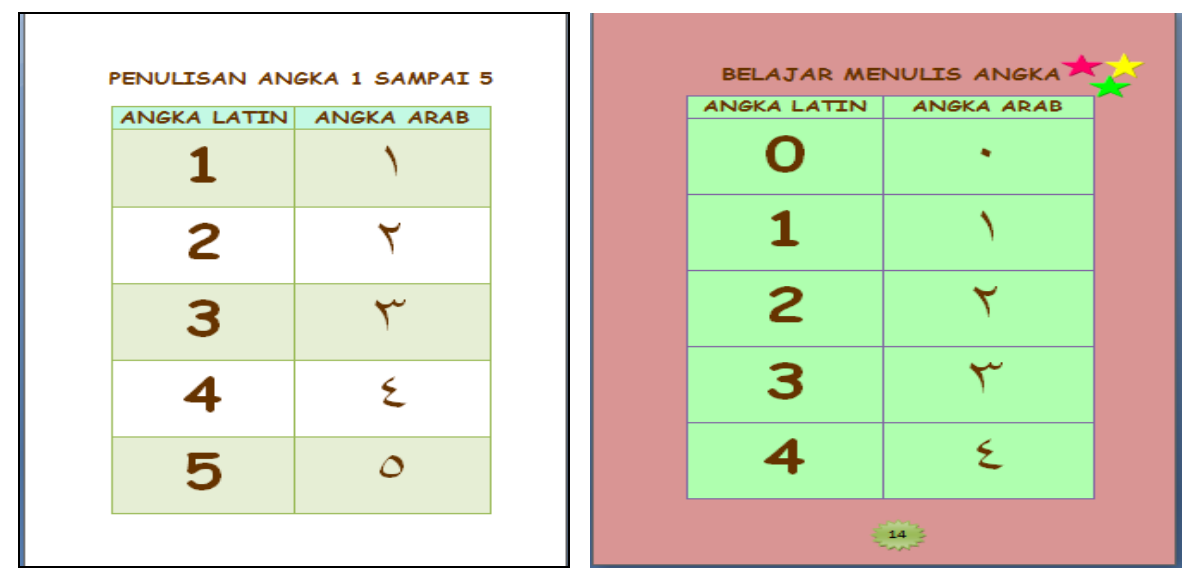

Gambar 4. Beberapa Isi Buku sebelum dan sesudah Revisi

\section{b. Tahap Praktikalitas}

Tahap ini dilakukan melalui kegiatan uji coba. Uji coba dilakukan setelah uji validasi oleh para ahli desain media pembelajaran dan ahli materi pembelajaran dilakukan terhadap buku keajaiban angka dalam Alqur'an. Uji coba dilakukan pada anak di TBA Hijaiyyah yang baru awal dalam mengenal angka dengan menggunakan lembar observasi. Berdasarkan perhitungan hasil analisis lembar observasi tersebut, diperoleh persentase secara klasikal sebesar 83,67\%. Dengan demikian dapat dijelaskan bahwa persentase keseluruhan dari penilaian para anak adalah layak atau baik sekali, karena berada pada rentang $81 \%$ sampai $100 \%$. Jadi buku keajaiban angka dalam Alqur'an Buku ini juga praktis digunakan untuk anak.

\section{Tahap penilaian (Assessment)}

Setelah buku diujicobakan kepada anak di TBA Hijaiyyah. Langkah selanjutnya yaitu mengadakan evaluasi terhadap kekurangan dari buku. Berdasarkan hasil dari uji coba lapangan, buku keajaiban angka dalam Alqur'an tidak memerlukan revisi. Hal ini tergambar dimana semua anak dapat menggunakan buku keajaiban angka dalam Alqur'an dengan baik dan suasana belajar tergambar begitu menyenangkan.

\section{SIMPULAN DAN SARAN}

Berdasarkan hasil penelitian yang telah dilakukan dapat disimpulkan bahwa telah dihasilkan buku keajaiban angka dalam Alqur'an dilengkapi media kartu angka yang valid dan praktis untuk digunakan bagi anak-anak di 
TBA Hijaiyyah. Valid tergambar dari hasil penilaian validator dimana semua validator menyatakan layak sekali. Sedangkan praktis tergambar dari hasil uji coba lapangan dimana semua anak dapat menggunakan buku keajaiban angka dalam Alqur'an dengan baik.

Untuk peneliti selanjutya, hendaknya dapat melakukan uji coba praktikalitas produk dengan skala yang lebih besar. Hal ini dilakukan agar dapat menghasilkan buku keajaiban angka dalam Alqur'an yang betul-betul praktis sesuai dengan keberagaman anak saat ini.

\section{DAFTAR PUSTAKA}

Akker, V. A. (1999). Design approaches and tools in education and training. Dortrech: Kluwer Academic Publishers.

Angkowo, R., \& Kosasih, A. (2007). Optimalisasi media pembelajaran. Jakarta: PT. Raja Grafindo Persada.

Arsyad, A. (2011). Media pembelajaran. Jakarta: PT. Raja Grafindo Persada.

Fitria, A. (2013). Mengenalkan dan membelajarkan matematika pada anak usia dini. Mu'adalah; Jurnal studi gender dan anak, 1(2), 45-55. Retrieved from http:/ / download.portalgaruda.org/ article.php?article=183200\&val=63 42\&title=Mengenalkan dan Membelajarkan Matematika Pada Anak Usia Dini

Hayuningtyas, H. (2014). Pemanfaatan sumber belajar dengan limbah kardus untuk mengembangkan konsep matematika permulaan anak usia 5-6 tahun (studi eksperimen di TK Taman Indria Semarang). Jurnal Early Childhood Education Papers (Belia), 3(1), 63-70. Retrieved from https://journal.unnes.ac.id/sju/index.php/belia/article/view/3422/3 090

Kurniati, A. (2015). Mengenalkan matematika terintegrasi islam kepada anak sejak dini. Suska Journal of Matematics Education, 1(1), 1-8. Retrieved from https://core.ac.uk/download/pdf/153775657.pdf

Lestariningrum, A. (2015). Pemanfaatan media biji-bijian sebagai sumber belajar bidang pengembangan matematika pada anak usia dini. Jurnal Efektor, 1(26), 12-18. Retrieved from http:/ / ojs.unpkediri.ac.id/index.php/efektore/article/download/71/39 
Maryani. (2010). Meletakkan dasar-dasar pengalaman konsep matematika melalui permainan praktis di kelompok bermain. Jurnal Pendidikan Penabur, 1(15), 1-11. Retrieved from http://bpkpenabur.or.id/wpcontent/uploads/2015/10/jurnal-No15-Thn9-Desemberi2010.pdf

Mohamed, M. (2004). Matematikawan muslim terkemuka. Jakarta: Salemba Teknika.

Mutiah, D. (2010). Psikologi bermain anak usia dini. Jakarta: Kencana.

Nurani, Y. (2012). Konsep dasar pendidikan anak usia dini. Jakarta: PT. Indeks.

Seefeldt, C., \& Wasik, B. A. (2008). Pendidikan anak usia dini menyiapkan anak usia tiga, empat, dan lima tahun masuk sekolah. Jakarta: PT. Indeks.

Sumantri, M. (2004). Media pembelajaran. Jakarta: Rineka Cipta.

Sumini. (2013). Meningkatkan kemampuan kognitif anak mengenal bilangan melalui media kartu angka. Jurnal UNESA, 2(1), 1-5. Retrieved from http://jurnalmahasiswa.unesa.ac.id/index.php/paudteratai/article/view/851/622

Tadkirotun, M. (2012). Pengembangan kecerdasan majemuk. Tangerang: Universitas Terbuka. 